\title{
7
}

\section{From Cyber Café to Smartphone: Kenya's Social Media Lens Zooms In on the Country and Out to the World}

\author{
Mark Kaigwa
}

\section{Introduction}

\section{End of the Cyber Café's Reign}

The cyber café has been described as an intermediary of the digital divide (Bhan 2011). In 2007, basic connectivity through General Packet Radio Service prevailed in Kenya for the nation's ten million mobile subscribers. Third-generation (3G) mobile telephony technology had yet to arrive, and mobile penetration stood at $28.97 \%$ (CA 2009). In that year, two new cellular mobile operators were licensed. Telkom Kenya (now trading as Orange) and Econet Wireless with its brand yuMobile (TeleGeography 2007) got set to take on Safaricom and Celtel. In March of that year, mobile network operator Safaricom launched its mobile money transfer

M. Kaigwa $(\bowtie)$

Nendo, Nairobi, Kenya

(C) The Author(s) 2017

B. Ndemo, T. Weiss (eds.), Digital Kenya,

DOI 10.1057/978-1-137-57878-5_7 
service, M-PESA. By the end of the same year, a milestone of one million registered users was reached (Safaricom.co.ke n.d.). So began a transformative epoch for Kenya's technology history.

In the developed world, one could consider the desktop computer as the gateway to the Internet — and perhaps even consider one's email address as a "passport" to the Internet. In Kenya, these two things were available to those who had access and could afford the cyber café as a physical location with Internet access and desktop personal computers.

Cyber cafés were seen as commercial ventures for entrepreneurial Kenyans (Bhan 2013). Cyber café attendants charged for per-minute use of desktop personal computers. Mobile Internet, though developing, was not as widespread. 3G service only came to Kenya in 2008 (Wanjiku 2008) for Safaricom, 2011 for Orange (TeleGeography 2011), and 2012 for Airtel (Mayton 2012).

Cyber café owners had seen the opportunity of connectivity and built on it. The list of services provided by cyber cafés included printing, lamination, and binding as well as typing - be it learning how or paying an attendee to type one's documents. It was not uncommon to see visitors charged to obtain an email address or open a profile on a social network. Facebook, the global social networking site based in Palo Alto, California, was growing in popularity since its launch in 2004. Cyber cafés began to realize this and had an incentive to help create Facebook accounts and profiles to increase customer frequency and usage in time spent online.

That said, as the hard-wired Internet reached parts of rural Kenya by 2009 (Wyche et al. 2013), so came changes in how urban and rural Kenyans experienced connectivity. However, usage was not equally distributed countrywide. For low-income rural Kenyans, accessing the Internet at a cyber café or on an Internet-enabled mobile phone represented a significant expenditure (Wyche et al. 2013) and Facebook was seen as a luxury.

Email became an important part of the cyber café ritual. Email was reported as the leading activity on the Internet (Ipsos Synovate 2011). The narrative of having an online mailbox to check for emails and using one's email address to sign up to receive communication led to the ascent of cyber cafés. As mobile telephony developed and more affordable devices were launched into the Kenyan market, the cyber café industry 
faltered. Cyber cafés, selling mobile broadband modems, would soon put themselves out of business with a key segment of their customer base, the casual or social browser-that is, those chatting on Instant Messaging, Facebooking, exchanging occasional emails, and so on-who seemed to cut down on their cyber visits. They were the largest segment of people going online (Bhan 2013).

Connected Kenya experienced a tectonic shift in the following four years, thanks to the arrival of the fiber optic cables. As slow and steady as the pace of growth was, M-PESA had taken off. Transfers on the mobile money network had reached Ksh. 23 billion by the time the fiber optic cables made landfall in June 2009. Facebook's growth by that time had seen 300,000 Kenyans users join (Lorica and O'Reilly Media 2009). With that, the net effects began to be felt in people's wallets. Speeds were expected to increase and become more reliable, while prices, which had been constant with very little motion in the market, were expected to slowly drop, and then, to continue doing so. As Calestous Juma noted in an interview, "The speed that knowledge currently moves in Africa is $5 \mathrm{mph}$ - walking pace. But with decent connectivity, knowledge will travel at the speed of light" (Rice 2008).

Habits began to transform too. In just the first 12 months after the fiber optic cables made landfall, the Internet-access point of Kenyans started shifting from cyber cafés to mobile phones (Ipsos Synovate 2010)—and the devices themselves were more widely available, with greater capacity to consume and connect to the Internet.

These shifts came about thanks in no small part to transformative devices and device partnerships, such as the historic Huawei IDEOS mobile phone. When Google, Huawei, and Safaricom saw that mobile Internet use had grown $180 \%$ in 2009-2010, they partnered to launch the IDEOS to accelerate this trend (Vota 2010). For Kenya, this was a watershed moment. The Android-powered touchscreen device sold more than 500,000 units (Okwii 2014). It was a true winner.

Priced at Ksh. 8500 (USD100), it came with 600 MB of data and Ksh. 1000 (USD10) worth of talk time. Seven of every ten phones sold in February 2011 were Huawei IDEOS phones. In that quarter, the phone single-handedly had $45 \%$ of market share in the smartphone segment as the most affordable smartphone in the market (Kemibaro 2011). By 
August of that year, more than 350,000 units had been sold as the phone went on course to break the half a million mark (Talbot 2012).

The shift taking place was one of space, in a sense, the physical spaces of connectivity were shifting. It was moving from being dominated by the static settings of cyber cafés to an increasingly mobile-driven world that included feature phones, smartphones, broadband modems, and laptop computers.

When it came to where Kenyans were spending their time online, another shift was also taking place. By the beginning of 2012, social networking had replaced email as Kenyans' number one activity on the Web, followed by entertainment, games, and music (Ipsos Synovate 2012).

It was now that online, too, a shift began to take place-that is, the spaces people were using to interact with one another. The key space was no longer the one built by email companies of the 1990s and 2000s, which had email at their core (with online groups driven by email, early social networks such as MySpace, or instant messaging clients such as Yahoo Messenger). On Opera Mini, a leading mobile browser, Facebook now ranked as the Number One most visited website by Kenyan users, solidifying its position and growing popularity (Opera Software 2010).

A prophetic remark from the past was about to come to fruition. Kwame Nkrumah, Ghana's founding president and the father of modernday Pan-Africanism, famously said, "We face neither East nor West, we face forward." For Kenya and the rest of Africa, at least for the connected class, a virtual manifestation of this was beginning to take place.

At the time, two Chinese technology companies, Huawei and Zhong Xing Telecommunication Equipment (China), were responsible for the telecoms infrastructures in 53 of 54 African countries (Zhongxiang 2011) — underpinning the fact that the East has one way in on the connectivity of Africans. They also manufactured most, if not all, of the devices that have been used to connect to the infrastructure and the Internet. But if you look to where Kenyans have spent their time online, you find that they look "West," spending their time on Facebook, Google, and other websites that have their main headquarters in Silicon Valley.

To better understand social media's growing influence, we need to examine the five years following the arrival of the fiber optic cables and see them in context through the lens of Twitter. Twitter began as a fledgling 
social network launched in 2006 at South by Southwest, an American technology and culture conference. The first Kenyan on Twitter, according to Digital Rand, a social media and blog tracking platform, is considered to be @kamuiri, a system administrator who signed up in March 2007 (Digital Rand 2014). The social network then began in earnest, with a flock of early adopters, including a number of bloggers following suit.

M-PESA's early adopters were "relatively upscale (and banked) male urban dwellers" (Omwansa et al. 2012). Twitter may have been no different. In M-PESA's case, users were transmitting more than Ksh. 100 million (about USD1.5 million) a day to their unbanked relatives all over the country, creating the very first core of M-PESA's users during the pilot phase, in 2007.

Twitter is perhaps best seen through the lenses of its hashtags over the years - each with its own description of a movement catalyzed and accelerated by the microblogging social network. They have ranged from the melodic, the culturally transcendent, the evocative, the terrorizing, the resplendent, and the heartwarming. Each day, dozens of trending topics catch the attention of Kenyans on Twitter, and a number cross from the virtual world into shaping outcomes for Kenyans on Twitter, legitimizing them for the world, for their leaders, and for themselves.

\section{The Backstory of Blogging and Kenya's Content Creators}

When it comes to Kenyan content creators, blogs trace back to an informal online community. The Kenya Bloggers Webring (KBW) was launched in 2003 by blogger Daudi Were of mentalacrobatics. com (Monitor 2015). It picked up the feeds of Kenyan authors online through Really Simple Syndication (RSS) feeds to help Kenyans read Kenyans - whether internationally or locally. There were even awards, dubbed the "Kaybees," given to members of the community and various publishers (Were 2006). As searches became more dominant and Kenyans, whether in the diaspora or at home, made searches for content closer to home, content creators found their audience coming to 
them. Searches of Kenyan topics became more likely to yield a variety of Kenyan-populated websites, including Kenya-focused message boards, forums, and even email listservs for those who still considered email their passport to the Internet. The largest Kenyan sites at the time blended the best of community forums and message boards with content sourced to spark conversations. In some ways, they could even be considered social networks (Obura 2009).

A frontrunner and innovator in this space was David Kobia's mashada. com, which was considered to be Kenya's most popular online forum, even being referenced as a news source (BBC 2008). It was a digital home away from home for Kenyans in Europe and the USA, with local connected Kenyans frequenting the discussions. It had such importance that during the 2007-2008 post-election violence, it had to be shut downand was called "Kenya's first digital casualty" - for the vitriolic and heated ethnic discussions going on around politics in the contested elections, mirroring Kenyan society at the time (Hersman 2008).

With the rise of Facebook, Mashada's star diminished as the almighty juggernaut of the globe took center stage. Though Mashada still had its faithful users, other diaspora-based message boards and websites competed for the attention of the 3.2 million Kenyans in the diaspora and cannibalized its audience.

Of Twitter, it can be said that the Kenyan users of the microblogging social network site were early adopters and bloggers. A steady flow of prominent Kenyan bloggers joined at the time, and many are still identifiable by their original blogging identities and pseudonyms to this day. They were seeking ways to use Twitter to build community outside of the existing comment sections, blogs, and email exchanges. For some, the purpose was to publicize their own content. Globally, it was not uncommon at the time for bloggers to slowly trade their longer forms of writing and communication for the faster-paced world of 140-character tweets.

The years 2007 and 2008 were significant in Kenya's history. As the members of the diaspora tried to keep in touch with those on the ground in Kenya during the country's post-election violence. Twitter was notable as one of the few sources where people sought the perspectives of Kenyans in Kenya. The news media and publishers were self-censoring or not representing the scale of the unrest. 
Ory Okolloh, with her digital space at kenyanpundit.com, started with a blog post asking, "Any techies out there willing to do a mashup of where the violence and destruction is occurring using Google Maps?" (Okolloh 2008). Her readers, who were also fellow bloggers with whom she had interacted frequently in the blogosphere, responded. Three days later-thanks to David Kobia, also a blogger at dkfactor.com; Erik Hersman, a blogger at WhiteAfrican.com; and Juliana Rotich, a blogger at Afromusing.com-Ushahidi was born (Goldstein and Rotich 2008).

Each of the founding members met because of their blogs. They had chosen and built their own digital community online and connected beyond borders, thanks to blogging. For Ushahidi, Twitter soon became the platform's input channel that it mapped across the world from crises to elections and emergencies. Ushahidi went on to make history as the quartet and the organization became a recognizable African technology brand-software for sifting through the complexities of multiple inputs from social networks, individual SMS texts, and other data points, all plotted geographically.

\section{The Rise of Kenyans on Twitter}

Looking at Twitter today, it is clear that it operates as Kenya's virtual "town square" (Kaigwa and Wu 2015). Journalists now consider it to be a part of their beat, staying tuned to trending blogs and other updates. It has become common to see news broken on Twitter by a bloggerwhether a hobbyist, informed industry insider, or cyber-roving reporter pouncing on a story-legitimizing it (at times, plagiarizing it outright!) and publishing it in the Kenyan news media. At least once a week, each of the daily and weekly newspapers sources and quotes tweets and other comments from social media.

News bulletins on Kenyan radio and television networks often make specific calls to action, whether the broadcast is in Swahili or English: "Tweet us your views" or "Our hashtag is..." and similar phrases. These are all appended to raise audience participation as announcers, newscasters, and stations promote a call to action. Some brands have even come to expect that social media will be part of their advertising package, and 
some Kenyan newspapers consider their social media audience as another channel for their clients' digital advertising.

As of 2016, only five of Africa's 54 countries have their own list of local trending topics on Twitter. For Kenya, this milestone proved to be a notable transition in Kenyan cyberculture. Previously, the focus for Kenyans had been the rest of the world's trending topics. If Kenya got a hashtag trending, it had to be on a global scale. During that time, when Kenyans referred to themselves as "trending," it was inevitably synonymous with worldwide trending, because this was the only way to see the social proof - that is, on Twitter's list of the "Worldwide Trends." However, starting on April 11 (Cheng-Yue 2013), there was now an in-country "micro-mirror" showing the daily, hourly, and minute-by-minute trending topics of Kenyans.

\section{Makmende: Meme, Muse, and Model}

In 2010, an eclectic house/funk/disco band consisting of Daniel Muli, Jim Chuchu, Bill Sellanga, and Mbithi Masya learned in their own way how their personal networks could catapult them to becoming one of Africa's first viral Internet sensations originating from Kenya (McKenzie 2010). Known as Just a Band, the group had been releasing a genrebending collection of electronic, funk, and Afro-pop hits for just over two years. Their next release, which launched in March 2010, would change African cyberspace.

The way that the band would raise awareness and create expectation for their singles was simple. They would ask close friends to change their profile pictures on social networks to an agreed-upon set of photographs prepared by the band. Their second single of their sophomore album " 82 " would be no different (Justabandwidth 2010). The band shared cryptic status updates to be published by their respective friends promoting "Ha He" proclaiming "Makmende Amerudi" ("Makmende Is Back") featuring images such as those of Makmende, a fictional Kenyan superhero character, from the soon-to-be-released music video on the cover of GQ, TIME, and Esquire magazines. The profile pictures and status updates created awareness and curiosity in the larger "degrees of 
separation" of friends of the band and in their social networks. Compared to their previous single, "Usinibore," of 2009 (Justabandwidth 2009), there was greater expectation. "Ha-He," with its blaxploitation theme, nostalgic filters, and quirky character references, drew urban Kenyans back to their upbringing in the 1990s and 1980s.

The music video was released in March 2010 and proved a roaring success. The built-up anticipation led not only to viewership on the band's YouTube channel, but soon to the establishment of Makmende as an Internet cultural icon, a meme, that others felt fully licensed to contribute to. The resonance of the video soon prompted other enterprising Kenyans to co-opt Makmende's currency as a variety of individuals created "fan art" about Makmende while others created websites such as www.makmende.com, impersonating the brand and likeness of Makmende. There was even a radio station that created a call-in game based on Makmende, all of which the band distanced themselves from, encouraging the trend to go on (BrandKemistry 2010).

Makmende's seeming invincibility led to a longstanding trending topic on Twitter that catalyzed it all through the hashtag \#Makmende, sparked by Kenyans who had watched the video. \#Makmende was lit up by the world as a global trending topic, making Twitter's top ten list for hours. It was viral. Across the world, Twitter users followed and joined in. The jokes about it took on a style perfected in Internet culture when referring to Hollywood martial artist Chuck Norris (Know Your Meme 2012). The recipe was to set up satirical factoids with absurdly exaggerated claims about Makmende's toughness, invincibility, fighting style, and masculinity. As the world chimed in with its comments, quips, and one-liners, the view count on the video rose and rose.

Kenyans on Twitter began to believe, following all the screenshots that were tweeted on the day, that no matter how few they were, they could not only get the digital ear of the world, but they could rally a global digital community to chip in. The Makmende phenomenon has been cited as an example of a transnational cultural flow originating in the Global South (Jenkins et al. 2013; Zuckerman 2010). The participatory playfulness around Makmende led to a "meme of aspiration" (Ekdale and Tully 2013), a meme through which a certain niche of Kenyans collectively reimagined a hypermasculine hero who could lead the country toward 
political and economic stability at home, and cultural and technological dominance abroad. Here, Ekdale and Tully's article (2013) drew from multiple texts about and within the Makmende meme, including videos, artwork, tweets, Facebook posts, blog messages, and news reports.

Makmende even featured in short films about voter registration produced by Just a Band as part of their civic-action creative campaign Kuweni Serious (Kiswahili for "Get serious") (Kuweni Serious 2010). From the first few tweets to the front cover of the Wall Street Journal online, the campaign made a historic statement in Internet culture.

Makmende also caused what would later be called a Wikipedia war, in which online editors deleted various attempts to create a Makmende page, citing rules such as copyright infringement, vandalism, or incomprehensibility. The phrase "Makmende's so huge, he can't fit in Wikipedia" was coined because the editors disagreed on whether the fictional character deserved a page.

This back-and-forth battle was characterized as one between inclusionists and deletionists (Ford 2011). For the deletionists, Makmende was an imaginary character from a small African country. He did not deserve a Wikipedia page, because, frankly, no one in the English-speaking world would really care about him. Although he was big in Kenya, he was not notable enough to deserve an encyclopedia entry (Zuckerman 2010).

\section{Digital Identity Spurs Drought Intervention}

In July 2011, digital marketing executive Ahmed Salim began a personal initiative around an impending drought and famine facing Kenya. The drought was described as the most severe since 1995 (UN OCHA 2011) and was anticipated to be the worst in 60 years (BBC 2011). Salim started with a pair of hashtags, \#SacrificeAMealKE and \#FeedKE, the latter of which he ultimately proceeded with. He noted that, a day after a plea to his timeline and followers, 58 people came forth to donate a meal to the Kenya Red Cross (Salim 2011a). A week later, he had raised Ksh. 140,880 from 172 people (Salim 2011b).

As the campaign gained momentum, it was adopted by the Red Cross, which later turned it into a national public-private partnership (Kenya 
Red Cross 2014). It was then launched into the public domain with a facelift, including a new title-\#KenyansforKenya-and corporate partners, including telecommunications company Safaricom and KCB Bank (formerly known as Kenya Commercial Bank). What started as a Twitter hashtag got people to act on their country's behalf and grew into a historic nationwide campaign.

The result was a national conversation that traversed Kenyan society, with endorsements by celebrities and other noteworthy Kenyans and touching montages and songs composed by the country's biggest artists. The giving was done by ordinary Kenyans, including individuals and institutions pledging to solve the crisis with their own local contributions. The campaign raised more than Ksh. 677 million, reaffirming the ability of Kenyans on Twitter to spark changes that touched the nation as a whole.

\section{Snippets in Cyberspace Lead to Songs in Public Space}

Also in 2011, spurred by the uprisings in Tunisia and Egypt, civil society groups in Kenya were inspired by conversations among Kenyans on social media, as they discussed what a local response similar to the Arab Spring might look like. From this, \#Kenya28Feb movement was born.

The call to action for the hashtag that turned into a movement was based on Kenyas national anthem. The anthem was originally composed as a prayer (Muindi 2015). The anthem is a common denominator for those who grew up singing it, hearing it, and committing it to memory as youth. For Kenyans of all faiths, ethnic backgrounds, interests, and socioeconomic backgrounds, the three verses of the national anthem were seen as a call for unity, not as an outright protest (Kenya 28 Feb 2011).

At 1:00 p.m. East African Time, Kenyans commemorated February 28 on the fourth anniversary of the signing of the National Peace Accord. The Accord had followed Kenya's 2007-2008 post-election violence, when the two principals formed what would become the coalition government (National Accord and Reconciliation Act 2012). 
Kenyans of all walks of life tweeted their photos, recorded audios of their singing, and even convinced co-workers, staff, and passersby to pause and sing. The movement was hosted by Inuka Kenya Trust, a grassroots advocacy group founded in 2009 by journalist and former anticorruption czar John Githongo. These events went on to last for another year, with an even larger campaign beforehand, featuring recognized Kenyan athletes, media personalities, and others.

\section{Medics Mobilize against Ministry before Masses}

In October 2012, Dr. Christine Sagini, a Kenyan doctor and member of the Kenya Medical Practitioners and Dentists Union, recounted howduring negotiations between the union and the Ministry for Medical Services-Minister Peter Anyang Nyong'o had "called medical doctors sulking children, crying for peremende" (Kiswahili for "sweets") (K24TV 2012). After this exchange and a breakdown in the negotiations, the doctors resolved to strike. "We'll tell Anyang Nyong'o and the world exactly what kind of peremendes we want," Dr. Sagini said in an interview with K24, a Kenyan television station. Irene Kimacia, the journalist on assignment, described the movement as "spreading like a bushfire (online), with 3,000 doctors tweeting their experiences to the public" (K24TV 2012).

The title of the campaign was "Thanks for your taxes, here is a sweet" (Peremende Movement 2012a). The name of the movement was a hidden reference to a certain Kenyan supermarket chain that was infamous for claiming to be out of loose change, particularly oneshilling coins, and offering shoppers their change in the form of sweets (Kajilwa 2015). The \#PeremendeMovement struck a chord with the public through a well-coordinated attempt by doctors to tweet in sync and through infographics, blog posts, and media appearances chronicling their challenges (Peremende Movement 2012b). The government, according to union Chairman Victor Ng'any, noted that after the protest, there was good will from the government in their negotiations (K24TV 2012). 


\section{Kenyans Online Make Their Voices Heard in Electoral Debates}

Twitter was gaining in legitimacy as a channel for those willing to try their cases in the court of public opinion, rallying the public to engage and amplify their messages.

The 2013 election stood out because it was the first one in which Kenya had a significant number of social media users. More than 1.8 million of Africa's 50 million Facebook users were in Kenya (Colic 2013), and there were hundreds of thousands of Kenyans on Twitter, all following and interacting with the candidates. The pre-election push ensured that voters were being courted in cyberspace ahead of the ballot.

The presidential debates stood out as an electoral event never seen before. The first of their kind in the country's history, the debates were geared toward putting the candidates before a global audience in cyberspace, with broadcasts on 8 television stations, on 32 radio stations, and on YouTube. The debates generated buzz both before the live event and then during it, with speculations on whether there would be only six main candidates or the full eight running for office. The frontrunners preferred fewer candidates, selected on the basis of polling data, while the media organizers pushed for more candidates, arguably to dilute conflict on-stage (Moss and O'Hare 2014). Anxiety crept in as it took a last-minute court decision to ensure that media organizers included fringe candidates lawyer Paul Muite and teacher Mohammed Dida. This court intervention further illustrated how contested and coveted the debate platform was, offeringespecially for the minor candidates - free and unparalleled publicity.

When asked if the presidential debates made a difference, Kenyan political analyst Kwendo Opanga remarked to the BBC that they had offered smaller parties a chance to shine in the eyes of the public (Okwembah 2013).

\section{Al-Shabaab versus the Administration: Twitter Amplifies Terror during Westgate Attack}

Later that year, the Westgate Mall attack would change the face of Kenyan history. At noon on Saturday, September 21, 2013, an agonizing attack began. Four gunmen associated with Al-Shabaab laid siege on the upscale 
Nairobi mall. However, their real-world actions had ramifications both in cyberspace and in real spaces, leaving 67 dead, 175 injured, and a nation in mourning.

The attack proved a watershed moment on social media. On one side were the aggressors, the four Al-Shabaab gunmen inside the mall. Authorities, first responders, and journalists descended on the scene but stood clear, with various security personnel going in. The public was put in a position not seen previously in terrorist attacks, watching through their phones and television screens as individuals trapped inside the mall sent updates into cyberspace. Some of these were pleas for help; others were messages to family or warnings to all who would see them.

Al-Shabaab, the terrorist group that claimed responsibility, was also online. The group had, as was common at the time, a pair of Twitter accounts, @HSMPress_ and @HSM_Press. From these accounts, members live-tweeted the siege and struck a chord of palpable fear. The exchanges in cyberspace involved the office of the President, the Ministry of Interior and Coordination of National Government, Al-Shabaab, various journalists, and Kenyans on Twitter on, and away from, the scene.

At 1:28 p.m. Kenyan time on September 22, the Kenyan military's official Twitter account announced that most of those trapped inside had been rescued and that "most parts" of the mall complex were under control (Anzalone 2013). The claim that the attack was nearly over was disproved in the early morning of September 23, when an explosion rocked the Westlands district of Nairobi (where the Westgate Mall is located). Larger explosions followed in the early afternoon. The siege would not be over for another day. Twitter and members of the public were served through blogger Robert Alai's timeline, as he found, verified, and tweeted updates on Westgateeven tweeting against the Kenya Defense Forces Twitter account when he deemed it necessary (Alai 2013). Alai was praised by fellow Kenyans on Twitter and recognized by the press for his work during Westgate, apart from his divisive day-to-day persona as a blogger and critic (Stieber 2013). 


\section{Private Developers Meet Match Thanks to Pupils, Protestors, and Pope}

Coming back from their Christmas holidays, students at Langata Road Primary School found an unusual fixture at their school. Their playground was no longer theirs. Fenced off with a stone wall and a green metal gate, it had been claimed by a private developer. Photojournalist and activist Boniface Mwangi, writing in a Facebook invitation to what he called the \#OccupyPlayground protest, called the developers "professional land grabbers acting on behalf of a very senior politician in the Jubilee government" (Mwangi 2015). The protest event, slated for January 19, 2015, was organized to donate sports equipment, according to the invitation, which received approximately 958 RSVPs from those who said they would attend.

On the day, clad in their green uniforms, students as young as 6 and as old as 14 joined Boniface and others protesting the land grab. In the group of attendees, placards with messages, such as "Uhuru government is protecting land grabbers," could be seen. Even Member of Parliament Kenneth Okoth was in attendance, along with police in full riot gear, in case the situation escalated. What started as a chanting of slogans by the students and protestors developed into an animated shaking open of the developer's gate and pushing down parts of the walls amidst loud cries and cheers.

The scene was volatile, and as protestors clashed with police, the police reacted by shooting tear-gas canisters into the crowd, sending the children scrambling. The scenes that followed were hard to watch-with children screaming, choking, and being rushed away amidst the clouds of smoke.

Skeptics judged the protestors, expressing cynicism for their use of the children, while opposition politicians tweeted shame on the government. It took an apology and a visit from the Minister for Interior and Coordination of National Government Major General (Ret.) Joseph Ole Nkaissery (Honan 2015). The political pressure that followed led to the naming of the private developers by Lands Cabinet Secretary Charity Ngilu (Waruinge 2015). The Pope in his visit to Kenya in November 2015 held a session with slum dwellers. He singled out land grabbing, 
specifically admonishing faceless "private developers who even grab playgrounds" and repeating the phrase "private developer," which had been used extensively on Twitter and in the media (Simiyu 2015).

\section{\#SomeoneTell the World: Kenyans on Twitter Make Their Mark}

However, when it comes to hashtags that engage the rest of the continent, nothing has quite had the longevity of the \#SomeoneTell hashtag. This hashtag is many things, most often a rallying cry for the country to put away digital divisions, cultural contrasts, and differing opinions-a call to arms that has Kenyans ready with their data bundles, Wi-Fi hotspots, keyboards, and keypads prepared to take digital aim at the latest target.

The first major instance of the hashtag's use was that of \#SomeoneTellCNN, in March 2012. On March 5 of that year, \#Kony2012, an online campaign and viral advocacy video by the American nonprofit advocacy group Invisible Children, was launched. The campaign urged the American public to use social media to put pressure on US leaders and celebrities in a bid to make guerilla group leader Joseph Kony "famous" (Invisible Children 2012). Described as the fastest-growing viral video of all time, the film reached 100 million views in 6 days, and 3.7 million people pledged support (Invisible Children 2012). The response was a tidal wave of headlines, attention, and spotlights shown onto Uganda from the USA and the West. This was not without Africans online voicing their opinions, many of them finding \#Kony2012 factually inaccurate, an oversimplification of a complex conflict, with a call to action that removed agency from those actually on the scene and on the ground in Gulu, Northern Uganda. There were also cries that the campaign was fraught with a "white savior complex," speaking to a Western predisposition to see and accentuate stereotypes about the continent's narratives of helplessness in the absence of interventions from foreign (i.e., Western) partners. Nigerian author Teju Cole famously wrote about Kony 2012, criticizing the backers' culture for supporting brutal policies in the morning, founding charities in the afternoon, and receiving awards in the evening (Cole 2012). 
Members of the African diaspora and significant numbers of local Africans decried the campaign (Jardin 2012), aiming not to let America and the world buy into its one-sided rhetoric. Outspoken Ugandan diaspora member TMS Ruge wrote an opinion piece in the New York Times to challenge the claims that Kony 2012 was a revolution (Ruge 2012).

\section{\#SomeonTellCNN: Where It All Began}

Even without the headlines and exchanges of \#Kony2012 having ceased, Uganda's neighbor, Kenya would have a case of its own to answer on the world stage. On March 11, 2012, CNN's East Africa correspondent David McKenzie filed a story about a grenade attack at a bus terminal in Nairobi that killed six people and injured more than 60 (BBC 2012). When the story went on air on the CNN International channel, anchor Jonathan Mann stood in front of an animated Kenyan flag emblazoned with the headline "Violence in Kenya." The flag and coverage of the story were interpreted as a skewed misrepresentation of the facts, because Kenyans were the victims of terror, not the perpetrators of it. And so, \#SomeoneTellCNN was born (Wamathai 2013).

The narrative behind CNN's coverage harkened back to various depictions of Kenya strung across international media during the 2007-2008 post-election violence. The same Kenyans who were connecting in cyber cafés at their leisure in years past were faced with experiencing or viewing on their TV screens as the world watched Kenya in chaos. A local media ban muzzled the Kenyan press from reporting on the post-election violence as it occurred but international media covered it extensively. Meanwhile, hateful SMSes were exchanged through mobile networks among Kenyans, thanks to mobile telephony (Goldstein and Rotich 2008). The country sank into a dark part of its history.

Kenyans tweeted the broadcaster and the journalist, thereby creating another global trending topic. \#SomeoneTellCNN was profane, profound, and piercing. Armed with satire, humor, facts, examples, and occasional insults, Twitter users made the case - globally — that the news report was a mistake and that their country deserved an apology. They got it. David McKenzie, the journalist who filed the story, was the first to 
apologize to Kenyans on Twitter, with a tweet acknowledging the inaccuracy of the reporting (McKenzie 2012).

For Africans who participated and joined Kenyans in calling on CNN for an apology, perhaps it was also fueled by the concurrent \#Kony2012 campaign discussions that disgruntled both local Africans and the diaspora. A place to vent frustration in the transient ebb and flow of Twitter trends, buoyed by the energy and agency of the young, connected continent on display for the world to see. \#SomeoneTell was on its way to becoming a hallmark of Kenyans on Twitter.

\section{\#SomeoneTellAfrica: Kenyans in Continental Combat}

Kenya began to use the \#SomeoneTell hashtag to combat other digital denizens in African countries. The list is lengthy. Kenyans, if asked, perceive that they have a $100 \%$ record of defeating foes large and small. These "cyber-wars" are often born out of news stories that broke on traditional media or in online publication. In the case of \#SomeoneTellUganda, an article insinuated that Kenya's President-elect Uhuru Kenyatta was actually a Ugandan. The story even carried a congratulatory message from the King of Bunyoro, Solomon Gafabusa Iguru, to his "cousin" Uhuru after he was confirmed as president. A newspaper carried pictures of relatives who looked like Kenyatta and even ran a follow-up story on how Jomo Kenyatta might have been Omukama Kabarega's son. Kenyans were livid and tweeted insults and memes, launching whatever they could to attack Ugandans on Twitter (Wambui 2013).

Another example is Botswanan Foreign Affairs and International Cooperation Minister Phandu Skelemani, who warned the Presidentelect not to set foot in Botswana should he refuse to cooperate with the International Criminal Court(Wambui 2013). Kenyans on Twitter (known as KOT) took this hard and started the hashtag \#SomeoneTellBotswana to defend their president and country. The uproar forced Skelemani to retract his statement and state that Kenya and Botswana would continue having a good relationship (BBC 2013).

\#SomeoneTellZimbabwe serves as a cautionary tale about the maturity of the hashtag. A Kenyan website with a quote from Zimbabwean 
President Robert Mugabe describing Kenyans as thieves touched a nerve of Kenyans (Spectator 2015). The resulting hashtag war with Zimbabweans began, only for Kenyans to realize that the article had been on a satirical website-something that had been clear all along to Zimbabweans on Twitter (known as Twimbos) (African Exponent 2016). A New York Times article by East Africa bureau chief Jeffrey Gettleman used the Mugabe quote in a damning article about corruption in Kenyas society - and a retraction was later issued when it emerged that even he had been duped (Gettleman 2015).

The hashtag was also used to send a message to the highest offices in the land; \#SomeoneTellUhuru and \#SomeoneTellKagame, for example, aimed to speak clearly to the heads of state in Kenya and Rwanda, respectively. American televangelists have been particularly notorious in some of their inaccurate statements, caught on video, about Kenya and have issued apologies and messages of reconciliation after encountering thousands of tweets correcting them (e.g., \#SomeoneTellTDJakes and \#Someone'TellPatRobertson).

\section{\#SomeoneTellCNN: Election-Fever Brings CNN}

In 2014, CNN's new East Africa correspondent Nima Elbagir filed her story "Armed and Ready to Vote" (Elbagir 2014), featuring a would-be militia group training and ready to defend themselves with what Elbagir described as "guns fashioned from iron piping, homemade swords, and bullets bought from the black market." She and the television network would draw the wrath of Kenyans on Twitter, Africans, and others worldwide.

Speaking with the chalk-faced leader of these militiamen rolling around doing somersaults on the ground and "ready for war," Elbagir thought she had found her big scoop and big break. Her prediction: Violence in Kenya's election. This was the second strike for CNN, and they were pronounced guilty once again. \#SomeoneTellCNN was back and just as vicious as before. A storm of tweets arose, aimed at the broadcaster and the journalist in question. The difference, this time, was that a new precedent was about to be set—offline. Dr. Bitange Ndemo, Permanent 
Secretary in the Ministry for Information and Communications at the time, relayed news from a National Security Committee meeting that morning with intelligence chiefs. He called CNN's coverage "stagemanaged" - a claim that CNN would later refute in its written apology. Ndemo said that CNN had planted the story in its international news and that the Kenyan government would protest vociferously, viewing it as irresponsibility of the highest order in a world news organization. He promised to write to CNN's world news headquarters to protest the piece, calling it propaganda that was causing chaos and expressing hope that CNN would retract it (Kenya Citizen TV 2013). This was the first time that the government had weighed in on a matter of national security inspired by and stoked on Twitter.

\section{\#SomeoneTellCNN: Presidents Set New Precedent against Media}

The year 2015 saw the third and possibly final "strike" for CNN—set on the largest stage so far. US President Barack Obama was set to grace the Global Entrepreneurship Summit, taking place in Kenya-and Kenya was preparing to welcome back its "son of the soil."

CNN America began its reportage with a Web story and initial tweet with the words "President Barack Obama is not just heading to his father's homeland, but to a hotbed of terror" (CNN 2015). This remark was followed with CNN's television broadcast and picked up by Kenyan observers in the diaspora and online. The phrase "hotbed of terror" was contested, even as it first appeared in numerous angles of coverage from CNN. It was repeated and appeared in text and in speech several times by various pundits and news anchors on the network. The live feed of the broadcast could not be watched in Kenya, but the screenshot sailed back and landed on the timelines of connected Kenyans, begging for a response. The onslaught of tweets made the global broadcaster modify the headline and opening of its story (Mullin 2015) away from "terror hotbed" to "father's homeland" (Hopkins 2015).

While there is no denying that there was some truth to the phrase, the description and outright characterization of the country as a resembling 
other global terror hotspots was a stretch (Mutiga 2015). Kenya had suffered a string of atrocities by the Somalia-based terror group Al-Shabaab, but most of Kenya did not resemble the parts of the world where terror attacks are commonplace, and the phrase was hence interpreted as reducing all the complexities of Kenya into a single narrative.

As the hashtag \#SomeoneTellCNN was reactivated once again, it was filled, this time around, with imagery and memes showing the country's diversity, beauty, landscapes, and urban life as Kenyans sought to counter the narrative with positive storytelling and captivating imagery. Kenyans on Twitter also got smarter with humor, satire, and quips making their case against $\mathrm{CNN}$ and its gaffe by ridiculing the broadcaster. The state of America was put under scrutiny, too, as the contradictions of US life were highlighted, including issues such as gun violence.

Kenyan media owner and industrialist Chris Kirubi proved to be one of the most popular commentators early on. Challenging $\mathrm{CNN}$, he praised the country's local investment opportunities, some of which he was going to be showcasing during the Global Entrepreneurship Summit. His key tweet was among the first to go viral: "Unless you are the one bringing the terror, we are a hotbed of investment opportunities \& great people" (Kirubi 2015).

The word "hotbed" made its way famously across cyberspace. Kenyans on Twitter rallied to show, through tweets, pictures, and videos, that their city was safe and the country had more to it than a headline. It also became a topic during the summit as "hotbed" was mentioned in two speeches from two different heads of state. President Uhuru Kenyatta, when opening the Global Entrepreneurship Summit, said that Kenya was a "hotbed of vibrant culture, natural beauty, and infinite possibility" to the audience's applause (Kenyatta 2015). The Global Entrepreneurship Summit's opening plenary session saw each keynote speaker react to the CNN headline. President Obama, President Kenyatta, and Julie Gichuru, the master of ceremonies, took turns at rewriting the headline, with President Obama adding that Kenya is a hotbed of innovation. Kenya was also referred to as a hotbed of entrepreneurship and of investment opportunity (Clarke 2016) - colossal endorsements that flew in the face of the original media story and implicitly sent a nod to Kenyans on Twitter. 
The government chose to issue a response as well. The highestranking intelligence officer in the government, Major General (Ret.) Joseph Nkaissery, the Cabinet Secretary for the Ministry of Interior and Coordination of National Government, spoke on the issue. At a press conference where he spoke in Kiswahili, he called the coverage "lies," describing the network's message as "propaganda" and ending by inviting an apology from CNN (Capital FM Kenya 2015). He would later be quoted as having termed CNN's actions a sustained campaign to portray Kenya in a bad light and its reportage as demonstrating irresponsibility and smacking of arrogance (Angira 2015). By then, it was not just the thousands of tweets that CNN would have to answer, but to the government of Kenya itself. As part of the fallout, a USD1 million advertising contract between Kenya and CNN was suspended (Murumba 2015a). The Kenya Tourism Board also said it was reacting to "misrepresentation of the country's status" (Murumba 2015b).

After the Global Entrepreneurship Summit, CNN sent one of its highest-ranking officers, Tony Maddox, to Kenya. The executive vice president and managing director for CNN International paid a personal visit to President Uhuru Kenyatta to deliver the network's apology in person. He said, "There is a world at a war with extremists; we know what a hotbed of terror looks like, and Kenya isn't one." He expressed regret and talked down any notion of the story as had been created in bad faith (Mutiga 2015). President Kenyatta, as part of his statement on their meeting, mentioned his disappointment and explained to Mr. Maddox why "Kenyans, as expressed by those on Twitter, were so angry" (Mutiga 2015).

\section{Conclusion}

Twitter remains for us a lens to view connected Kenyans as a whole. The nation's sense of belief in the power of technology to bring about change, shift dialogue, and present a narrative now plays out both on a smaller stage for local trending topics and sometimes on the larger stage of the world as a whole.

Each day, as Kenyans wake up, they receive the mainstream media with its headlines and news. They also have Twitter's list of local trending 
topics - an algorithmically generated service that takes popular and emerging trends and showcases them. While Kenya may no longer trend globally as much because of this, there is now a local lens to study the habits of connected Kenyans at a far more granular level.

As became clear while researching and creating the A-Z of Kenyan Twitter website, a need remains for exploring and understanding the depth and breadth of Pan-African digital society and culture (Kaigwa and Nendo 2014). The pace of which African nations with local trending topics such as Kenya, South Africa, Nigeria, Ghana, Algeria, and Egypt continue to create cyberculture invites examination. The role of the mobile phone has ensured a place for Twitter in Kenyan hearts, minds, and headlines (Nzomo 2014), but the journey is far from over. What new paradigms will arise with the African uptake of new social media platforms? What is to be said of a world where social media "self destructs" akin to image-based messaging app and social network Snapchat? Digital dictionaries such as A-Z of Kenyan Twitter can be considered as emerging media formats to guide locals and internationals to provide greater African context and perhaps even lead to greater global understanding.

What of a world where visual social media dominates the globe and challenges stereotypes? In 2015, the Twitter hashtag \#TheAfricaTheMediaNeverShowsYou brought forward the work of Instagram users, both professional photographers and hobbyists, with pictures of African capital cityscapes and vignettes of life on the continent that challenged Western media and global stereotypes of disaster and catastrophe (Banning-Lover, 2015). Will we see less of these as Africans evolve with the social media and mobile times?

WhatsApp, the instant-messaging application, which is owned by Facebook, can be considered to be the future of social networking, having been built entirely around the mobile phone, contacts, and minimal data usage. WhatsApp can take the place of Kenya's largest social networkdespite its appearance as an instant messaging application. This shift from its perception and packaging as an instant messaging mobile app to an informal social network was predicted as a key trend for Kenya's social media evolution (Kaigwa et al. 2014). The app will take on a greater role as a pseudo social network made up of groups and potentially businesses in 2016 and beyond (WhatsApp Inc. 2016). More mindful work, 
targeted at a profound understanding of Africa's cyberculture, is needed to answer these and many more questions that will allow us to better feel the pulse of contemporary society.

And thus has the paradigm fully shifted from cyber cafés to mobile phones and, from there, to the niche network Twitter, which presently remains a leading public platform in Kenya's digital economy. While the platform faces a tough time in determining its future in the USA (Constine 2016), its prospects in Kenya-and Kenya's belief in itremain bright, even though it as no guarantee on its position.

\section{References}

African Exponent. (2016). \#KenyaVsZimbabwe: Kenya's cyber-bullying tactic and misguided Twitter tirade. https://www.africanexponent.com/post/kenyascyberbullying-tactic-and-misguided-twitter-tirade-1082. Accessed 17 Mar 2016. Alai, R. (2013). Interior ministry not helping with wrong info. Building is on fire on LIVE TV while you claim it has been put out. \#WestgateAttack. Twitter. https://twitter.com/RobertAlai/statuses/382190027398062081. Accessed 10 Mar 2016.

Angira, Z. (2015). Kenya protests at CNN broadcast. http://www.nation.co.ke/ news/Joseph-Nkaissery-CNN-of-smear-campaign-against-Kenya//1056/2804434/-/3cwtme/-/index.html. Accessed 17 Mar 2016.

Anzalone, C. (2013). The Nairobi attack and Al-Shabab's media strategy. CTC Sentinel, 6(10). https://www.ciaonet.org/attachments/23804/uploads. Accessed 17 Mar 2016.

Banning-Lover, R. (2015). The Africa the media never shows you - in pictures. http://www.theguardian.com/global-development-professionalsnetwork/2015/jun/30/the-africa-the-media-never-shows-you-in-pictures. Accessed 31 Mar 2016.

BBC. (2008). Battle of the blogs in Kenya. http://news.bbc.co.uk/2/hi/ africa/7189291.stm. Accessed 9 Mar 2016.

BBC. (2011). Horn of Africa tested by severe drought. http://www.bbc.com/news/ world-africa-14023160. Accessed 15 Mar 2016.

BBC. (2012). Kenya blames al-shabab for deadly Nairobi grenade attack. http:// www.bbc.com/news/world-africa-17326086. Accessed 12 Mar 2016.

BBC. (2013). Botswana apologises to Kenya over Kenyatta ICC warning. http:// www.bbc.com/news/world-africa-21784867. Accessed 13 Mar 2016. 
Bhan, N. (2011). The role of the cyber cafe. Nitibhan.com. http://nitibhan. com/2011/10/31/the-role-of-the-cyber-cafel. Accessed 15 Mar 2016.

Bhan, N. (2013). Impact of mainstreaming and commodification of cyber cafe services. Nitibhan.com. http://nitibhan.com/2013/05/04/impact-ofmainstreaming-and-commodification-of-cyber-cafe-services/. Accessed 16 Mar 2016.

Brandkemistry. (2010). Official statement from just a band about Makmende. https://brandkemistry.wordpress.com/2010/03/30/official-statement-fromjust-a-band-about-makmende/. Accessed 17 Mar 2016.

Capital FM Kenya. (2015). Apologise in the interest of civility, Kenya tells CNN. Capital FM Kenya Youtube Channel. https://www.youtube.com/ watch?v=xbUbdjx-o4A. Accessed 17 Mar 2016.

Cheng-Yue, R. (2013). Trends in 160+ locations | Twitter blogs. Twitter Blog. https://blog.twitter.com/2013/trends-in-160-locations. Accessed 1 Mar 2016.

Communications Authority of Kenya (CA). (2009). Communications statistics report second quarter 2008/09. http://ca.go.ke/images/downloads/ STATISTICS/Sector\%20Statistics\%20Report\%20Q2\%202008.pdf. Accessed 2 Mar 2016.

Constine, J. (2016, February 10). Twitter's monthly user count actually shrunk if you exclude SMS. Techcrunch. http://techcrunch.com/2016/02/10/twitteris-shrinking/. Accessed 17 Mar 2016.

CNN. (2015). President @BarackObama isn't just heading to his father's homeland, but to a hotbed of terror. Http://t.co/OkTE671wfe. Twitter. https://twitter.com/CNN/status/624006935218647040. Accessed 12 Mar 2016.

Clarke, T. (2016). Kenya: It's a hotbed of what? Africa.com. http://www.africa. com/kenya-its-a-hotbed-of-what/. Accessed 14 Mar 2016.

Cole, T. (2012). 2- the white savior supports brutal policies in the morning, founds charities in the afternoon, and receives awards in the evening. Twitter. https:// twitter.com/tejucole/status/177809558608150529?ref_src=twsrc\%5Etfw. Accessed 17 Mar 2016.

Colic, I. (2013). Afrographique (an overview of the latest user numbers in the...). Afrographique. http://afrographique.tumblr.com/post/46417790373/anoverview-of-the-latest-user-numbers-in-the. Accessed 26 Feb 2016.

Digital Rand. (2014). State of social media in Kenya. http://digitalrand.com/ resources/reports/A002.pdf. Accessed 2 Mar 2016.

Ekdale, B., \& Tully, M. (2013). Makmende Amerudi: Kenya’s collective reimagining as a meme of aspiration. Critical Studies in Media Communication, 31(4), 283-298. doi:10.1080/15295036.2013.858823. 
Elbagir, N. (2014). Armed as Kenyan vote nears. CNN. http://edition.cnn.com/ videos/\#/video/international/2013/02/28/elbagir-kenya-armed.cnn?iref=allsearch. Accessed 16 Mar 2016.

Ford, H. (2011). This missing wikipedians. Networkcultures.org. http://www. networkcultures.org/_uploads/\%237reader_Wikipedia.pdf. Accessed 17 Mar 2016.

Gettleman, J. (2015). An anticorruption plea in Kenya: 'Please, just steal a Little'. New York Times.:http://www.nytimes.com/2015/11/05/world/africa/ kenya-government-corruption.html?_r=0. Accessed: 15 Feb 2016.

Goldstein, J., \& Rotich, J. (2008). Digitally networked technology in Kenya's 2007-2008 post-election crisis. Berkman Center Research Publication, 2008-9.

Hersman, E. (2008). Mashada forums: Kenyas first digital casualty. WhiteAfrican. http://whiteafrican.com/2008/01/29/mashada-forums-kenyas-first-digitalcasualty/. Accessed 15 Mar 2016.

Honan, E. (2015). Kenyan officials condemn use of tear gas at children's protest. Reuters. http://www.reuters.com/article/us-kenya-police-playgroundidUSKBN0KT1U020150120. Accessed 17 Mar 2016.

Hopkins, C. (2015). Kenyans launch hashtag campaign after CNN calls their country a 'terror hotbed. Dailydot. http://www.dailydot.com/politics/cnnkenya-terrorism-twitter-hashtag/. Accessed 17 Mar 2016.

Invisible Children. (2012). KONY 2012. Invisible Children Youtube Channel. https://www.youtube.com/watch?v=Y4MnpzG5Sqc. Accessed 13 Mar 2016. Ipsos Synovate. (2010). Kenya Audience Research Foundation Establishment Survey, Q4.

Ipsos Synovate. (2011). Kenya Audience Research Foundation Establishment Survey, Q1.

Ipsos Synovate. (2012). Kenya Audience Research Foundation Establishment Survey, Q1.

Jardin, X. (2012). African voices respond to hyper-popular Kony 2012 viral campaign. BoingBoing. http://boingboing.net/2012/03/08/african-voicesrespond-to-hype.html. Accessed 5 Mar 2016.

Jenkins, H., Ford, S., \& Green, J. (2013). Spreadable media: Creating value and meaning in a networked culture. New York: New York University Press. Justabandwidth. (2009). Just a band - Usinibore. Justabandwidth Youtube Channel. https://www.youtube.com/watch?v=43XrFVp-fXY. Accessed 8 Mar 2016. Justabandwidth. (2010). Just A band - Ha-He. Justabandwidth Youtube Channel. https://www.youtube.com/watch?v=_mG1vIeETHc. Accessed 17 Mar 2016. 
K24TV. (2012). Peremende movement: Give us the 'sweets'. K24TV Youtube Channel. https://www.youtube.com/watch?v=9VPpfYN72zU. Accessed 17 Mar 2016.

Kaigwa, M., Madung, O., \& Bajaber, S. (2014). The 2014 Nendo social media trend report. Nendo.co.ke. http://report.nendo.co.ke. Accessed 20 Feb 2016.

Kaigwa, M., \& Nendo. (2014). The A to $Z$ of Kenyan Twitter. Nendo.co.ke. http://atoztwitter.nendo.co.ke. Accessed 17 Mar 2016.

Kaigwa, M., \& Wu, Y.-S. (2015). \#MadeInAfrica: How China-Africa relations take on new meaning thanks to digital communication. In A. Gadzala (Ed.), Africa and China: How Africans and their governments are shaping relations with China (1st ed., pp. 149-170). Lanham: Rowman \& Littlefield Publishers.

Kajilwa, G. (2015). Central Bank of Kenya warns supermarkets against offering sweets for change. Standard Media. http://www.standardmedia.co.ke/business/article/2000178395/central-bank-of-kenya-warns-supermarketsagainst-offering-sweets-for-change. Accessed 17 Mar 2016.

Kemibaro, M. (2011). The Huawei IDEOS sells over 60, 000 units in Kenya. Moses Kemibaro. http://www.moseskemibaro.com/2011/05/17/the-huaweiideos-sells-over-60000-units-in-kenya/. Accessed 23 Feb 2016.

Kenya 28 Feb. (2011). Why 28 Feb? Kenya28Feb. http://28feb.co.ke/whats-theplan/why-february-28th/. Accessed 17 Mar 2016.

Kenya Citizen TV. (2013). Bitange Ndemo's reaction to CNN video. Kenya Citizen TV Youtube Channel. https://www.youtube.com/watch?v=ugW1L_ 0w3z4. Accessed 17 Mar 2016.

Kenya Red Cross. (2014). Kenyans 4 Kenya archive. Kenya Red Cross. http:// www.kenyaredcross.org/index.php/kenyans-for-kenya. Accessed 8 Mar 2016.

Kenyatta, U. (2015). Speech by H.E. Uhuru Kenyatta during the opening of the Global Entrepreneurship Summit. Scribd. http://www.scribd.com/ doc/272541000/Speech-By-H-E-Uhuru-Kenyatta-During-the-Opening-ofthe-Global-Entrepreneurship-Summit. Accessed 19 Mar 2016.

Kirubi, C. (2015). Unless you are the one bringing the terror, we are a hotbed of investment opportunities \& great people \#SomeoneTellCNN. Twitter. https://twitter.com/CKirubi/status/624137472822411264. Accessed 25 Feb 2016.

Know Your Meme. (2012). Makmende. http://knowyourmeme.com/memes/ makmende. Accessed 17 Mar 2016.

Kuweni Serious. (2010). Save yourself. Vote. (frustrated hawker). Kuweni Serious on Youtube Youtube Channel. https://www.youtube.com/watch? v=DbSc1UvGs6s. Accessed 17 Mar 2016. 
Lorica, B., \& O'Reilly Media. (2009, June 17). Active Facebook users by country \& region. Slideshare. http://www.slideshare.net/oreillymedia/active-facebookusers-by-country-region-june-2007/10-South_America_Active_Users_By. Accessed 17 Mar 2016.

Mayton, J. (2012). IT news Africa-Africa's technology news leader. ITNews Africa. http://www.itnewsafrica.com/2012/02/airtel-kenya-launches-3g-network/ Accessed 16 Mar 2016.

McKenzie, D. (2010). Video news. CNN. http://cnn.com/video/?/video/ world/2010/03/31/mckenzie.kenya.viral.sensation.cnn. Accessed $8 \mathrm{Mar}$ 2016.

McKenzie, D. (2012). Our reporting on last night was accurate, the banner used in bulletin was not. I contacted CNN for future bulletins. Apologies to all. Twitter. https://twitter.com/McKenzieCNN/status/178794841663217664. Accessed 7 Mar 2016.

Monitor. (2015). The state of blogging and social media. http://www.monitor. co.ke/wp-content/uploads/2015/06/The-State-of-Blogging-and-SocialMedia-in-Kenya-2015-report.pdf. Accessed 16 Mar 2016.

Moss, N., \& O’Hare, A. (2014). Staging democracy: Kenya’s televised presidential debates. Journal of Eastern African Studies, 8(1), 78-92. doi:10.1080/17531055.2013.869929.

Muindi, B. (2015). How Kenya's national anthem was composed and the men behind it. Tuko. https://tuko.co.ke/64646-how-kenyas-national-anthemwas-composed-and-the-men-behind-it.html. Accessed 31 Mar 2016.

Mullin, B. (2015). CNN calls Kenya "hotbed of terror," sparks \#Someone TellCNN. Poynter. http://www.poynter.org/2015/cnn-calls-kenya-hotbed-of-terrorsparks-someonetellcnn/360133/. Accessed 20 Mar 2016.

Murumba, S. (2015a). Kenya promotion deal with CNN still suspended despite apology. Business Daily Africa. http://www.businessdailyafrica.com/ Corporate-News/No-advertising-deal-with-CNN-despite-apology-KTBboss-says/-/539550/2834914/-/c254iaz/-/index.html. Accessed 17 Mar 2016. Murumba, S. (2015b). Kenya suspends CNN deal over terrorism slur. Business Daily Africa. http://www.businessdailyafrica.com/Kenya-suspends-CNN-deal-overterrorism-slur/-/539546/2822870/-/qliv68/-/index.html. Accessed 17 Mar 2016.

Mutiga, M. (2015). CNN executive flies to Kenya to apologise for 'hotbed of terror' claim. The Guardian. http://www.theguardian.com/world/2015/ aug/14/cnn-kenya-apologise-obama. Accessed 17 Mar 2016.

Mwangi, B. (2015). \#OccuppyPlayGround. https://www.facebook.com/ events/378529712319607/. Accessed: 19 Mar 2016. 
National Accord and Reconciliation Act. (2012). Kenya Law. http://kenyalaw. $\mathrm{org} / \mathrm{kl} /$ fileadmin/pdfdownloads/Acts/NationalAccordandReconciliationAct_ No4of2008.pdf. Accessed 12 Mar 2016.

Nzomo, V. (2014). Public law and social media use by state officers: Lessons from chief justice Twitter spat with former registrar. CIPIT Blog. https://cipitblog.wordpress. com/2014/11/04/public-law-and-social-media-use-by-state-officers-lessonsfrom-chief-justice-twitter-spat-with-former-registrar/. Accessed 17 Mar 2016.

Obura, F. (2009). Social networking sites a boon for webmasters. Standard Media. http://www.standardmedia.co.ke/article/1144010249/social-networkingsites-a-boon-for-webmasters. Accessed 3 Mar 2016.

Okolloh, O. (2008). Update Jan 3 11:00 pm. Kenyan Pundit. http://www. kenyanpundit.com/2008/01/03/update-jan-3-445-1100-pm/. Accessed 9 Mar 2016.

Okwembah, D. (2013). Did Kenya presidential debate make a difference? BBC. http://www.bbc.com/news/world-africa-21430278. Accessed 17 Mar 2016.

Okwii, D. (2014). Which mobile vendor will deliver the ultimate $\$ 50$ smartphone for Africa? Dignited. http://www.dignited.com/10896/mobile-vendor-willdeliver-ultimate-50-smartphone-africa/. Accessed 17 Mar 2016.

Omwansa, T. K., Sullivan, N. P., \& Guardian, T. (2012). Amazon.com: Money, real quick: The story of M-PESA (guardian shorts book 22) eBook. http://www. amazon.com/Money-Real-Quick-M-PESA-Guardian-ebook/dp/ B007FPP7NI/ref=sr_1_1?ie=UTF8\&qid=1458210629\&sr=8-1\&keywords $=$ money+real+quick. Accessed 19 Mar 2016.

Opera Software. (2010). State of the mobile web. http://media.opera.com/media/ smw/2010/pdf/smw062010.pdf. Accessed 17 Mar 2016.

Peremende Movement. (2012a). Peremende movement. https://peremende. wordpress.com/. Accessed 17 Mar 2016.

Peremende Movement. (2012b). Pay our doctors. https://peremende.wordpress. com/2012/10/03/pay-our-doctors/. Accessed 17 Mar 2016.

Rice, X. (2008). Internet: Last piece of fibre-optic jigsaw falls into place as cable links east Africa to grid. The Guardian. http://www.theguardian.com/technology/2008/aug/18/east.africa.internet. Accessed 17 Mar 2016.

Ruge, T. (2012). 'Kony 2012' is not a revolution. New York Times. http://www. nytimes.com/roomfordebate/2012/03/09/kony-2012-and-the-potential-ofsocial-media-activism/kony-2012-is-not-a-revolution. Accessed 17 Mar 2016. Safaricom.co.ke. (no date). Celebrating 9 years of changing lives. http://www.safaricom.co.ke/mpesa_timeline/timeline.html. Accessed 16 Mar 2016. 
Salim, A. (2011a). After 1 WEEK - \#FeedKE. Ahmed Salims. http://ahmedsalims.com/post/8117754664/after-1-week-feedke. Accessed 17 Mar 2016.

Salim, A. (2011b). 'Dear Kenyans..', 100 \% KENYAN!!!. Ahmed Salims. http:// ahmedsalims.com/post/7837442344/dear-kenyans. Accessed 17 Mar 2016.

Simiyu, O. (2015). End land injustices, pope Francis says. The Nation. http:// www.nation.co.ke/news/-/1056/2974348/-/13iojnnz/-/index.html. Accessed 19 Mar 2016.

Spectator. (2015). Robert Mugabe - God should never have created those thieves (Kenyans) here in Africa. http://www.spectator.co.ke/2015/11/robertmugabe-god-should-never-have-created-those-thieves-kenyans-here-inafrical. Accessed 1 Mar 2016.

Stieber, Z. (2013). Robert Alai, Kenyan Blogger, earns praise for coverage of terror attack at Westgate mall. The Epoch Times. http://www.theepochtimes.com/ n3/296998-robert-alai-kenyan-blogger-earns-praise-for-his-coverage-ofkenya-terror-attack-at-westgate-mall/. Accessed 20 Mar 2016.

Talbot, D. (2012). Android marches on east Africa. MIT Technology Review. https://www.technologyreview.com/s/424454/android-marches-on-eastafrical. Accessed: 17 Mar 2016.

TeleGeography. (2007). Econet plans 2008 launch. https://www.telegeography. $\mathrm{com} /$ products/commsupdate/articles/2007/07/20/econet-plans-2008launch/. Accessed 17 Mar 2016.

TeleGeography. (2011). Telkom Kenya launches $3 G$ in Nairobi, Mombasa, Kisumu. https://www.telegeography.com/products/commsupdate/articles/2011/08/26/telkom-kenya-launches-3g-in-nairobi-mombasa-kisumu/. Accessed 16 Mar 2016.

UN Office for the Coordination of Humanitarian Affairs (OCHA). (2011). Eastern Africa drought humanitarian report no. 3. http://reliefweb.int/report/ burundi/eastern-africa-drought-humanitarian-report-no-3. Accessed $17 \mathrm{Mar}$ 2016.

Vota, W. (2010). \$100 Huawei Android mobile phone is bringing the netbook revolution to smartphones. ICTworks. http://www.ictworks.org/2010/09/07/100huawei-android-mobile-phone-bringing-netbook-revolution-smartphones/. Accessed 7 Mar 2016.

Wamathai, J. (2013). What \#SomeoneTellCNN is all about [Updated]. Hapa Kenya. http://www.hapakenya.com/someonetellcnn-trending-worldwide/. Accessed 25 Feb 2016.

Wambui, B. (2013). We are legion: Why Kenya's next war will be on Twitter. The Nation. http://www.nation.co.ke/Features/DN2/-/957860/1941640/-/ e8xvxk/-/index.html. Accessed 9 Mar 2016. 
Wanjiku, R. (2008). Safaricom launches $3 G$ technology. Network World. http:// www.networkworld.com/article/2280369/network-security/safaricomlaunches-3g-technology.html. Accessed 16 Mar 2016.

Waruinge, M. (2015). Trending: Private developer behind Langata land grab named - kiss FM. Kiss100. https://kiss100.co.ke/trending-private-developerbehind-langata-land-grab-named/. Accessed 8 Mar 2016.

Were, D. (2006). Kaybees - The Kenyan blog awards (2006). Mentalacrobatics. http://mentalacrobatics.com/2006/03/kaybees_the_kenyan_blog_ awards_2006/. Accessed 17 Mar 2016.

WhatsApp Inc. (2016). Making WhatsApp free and more useful-WhatsApp blog. WhatsApp Blog. https://blog.whatsapp.com/615/Making-WhatsApp-freeand-more-useful. Accessed 2 Mar 2016.

Wyche, S. P., Schoenebeck, S. Y., \& Forte, A. (2013). 'Facebook is a luxury': An exploratory study of social media use in rural Kenya. Andrea Forte. http://www. andreaforte.net/WycheFacebookCSCW13.pdf. Accessed 17 Mar 2016.

Zhongxiang, Z. (2011). China report. China Africa. http://www.chinafrica.cn/ china_report/txt/2011-01/02/content_322394.htm. Accessed 17 Mar 2016. Zuckerman, E. (2010). Makmende's so huge, he can't fit in Wikipedia. ... My heart's in Accra. http://www.ethanzuckerman.com/blog/2010/03/24/ makmendes-so-huge-he-cant-fit-in-wikipedia/. Accessed 3 Mar 2016. 


\title{
Conversation \#7
}

\author{
Toward Digitizing Information \\ for the Benefit of the Many Rather \\ Than the Few
}

Munyutu Waigi of Umati Capital

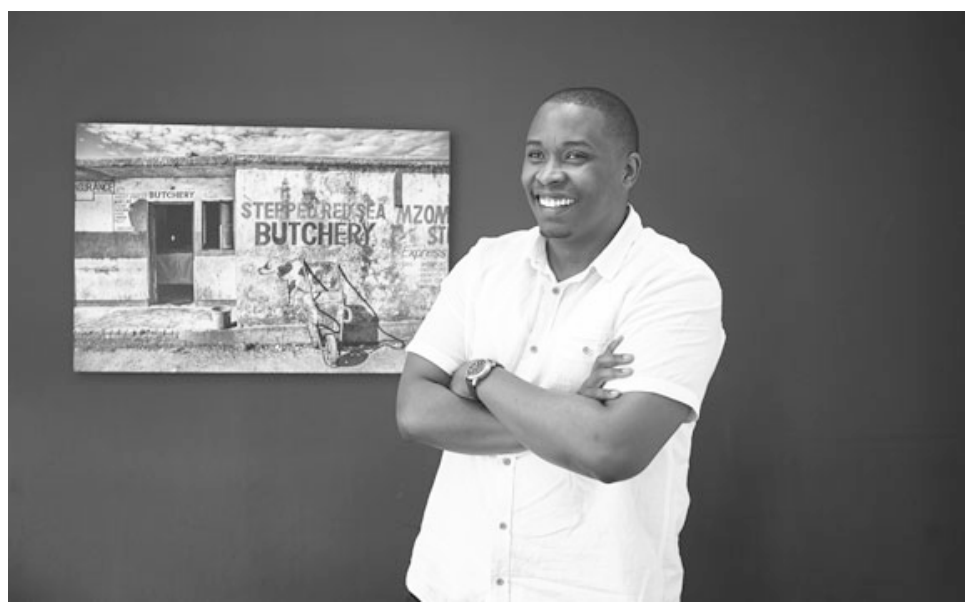

Munyutu Waigi was raised in Mombasa and left for England when he was 13 years old. The technology bug bit him when he worked in information technology (IT) support for the Williams Formula One racing team as part of his fouryear degree program at London's Brunel University, where he studied information systems. After graduating, he joined the global management consultancy Accenture, working in communications and high tech. The urge to do something much bigger that would challenge him became overwhelming - and he decided to quit three months short of his three-year anniversary at the firm. He moved back to Mombasa to start all over again and set up MoComm 
Wireless, a Wi-Fi company. About year and a half later, he finally got his big break. Along with Leandro Sanchez, he co-founded Rupu, a group buying website that has become Kenya's largest e-commerce firm. Two years later, Munyutu cashed out and used the funds to start his life's true work: And that is pretty much the beginning of Umati Capital.

\section{Munyutu, what is the story behind Umati Capital?}

In a nutshell, Umati Capital is an innovative tech-based lending institution. We primarily lend to processors and exporters across the agriculture sector. Umati provides working capital, invoice discounting, and supply chain financing solutions to bridge challenging 30-, 45-, 60- or 90-day payment terms faced by suppliers.

\section{How does the digital solution work in practice?}

Take, for example, the coconuts value chain. There is the farmer who grows the coconuts, and in turn, sells them to a processor-exporter who extracts value and sells the compressed oil to international buyers across the USA and UK. Having purchased coconuts from hundreds of farmers, the processor-exporter has usually less than 30 days to settle the debt-but unfortunately has to wait 45 days to receive payments from his or her international buyers. This leaves a funding gap that the processor-exporter has to plug. Instead of approaching banks, which require collateral and lengthy processing times, the processor-exporter has Umati Capital as a premier solution provider. Unlike banks, Umati Capital does not require collateral to lend to the processor-exporter. Furthermore, we offer technologies, such as mobile and web apps, that help digitize the processor-exporter's purchasing process, which is usually very manual. All in all, Umati Capital offers seamless financing along with innovative technology - a value proposition most banks can't match.

\section{How will your solution affect the agribusiness value chain?}

According to recent statistics, there are 700 million people across Africa engaged in agricultural activities. That is seven-tenths of Africa's population, considering recent estimates of just over a billion people. This is further compounded in Kenya, where statistics have shown that 
agriculture contributes $25 \%$ of the Kenyan gross domestic product (GDP). Surprisingly, only $4 \%$ of bank lending supports this key pillar in our economy. Why? Perhaps it has a lot to do with the fact that the key actors (farmers) do not have credit profiles - the basis of most structured lending - that would give traditional lenders comfort in their economic activity.

How is Umati Capital addressing this issue? The majority of assistance (international and local) to the agricultural sector has been tackling the issue from ground up. At Umati Capital, we believe the opposite: The issue has to be tackled from the top down. You can argue that there are several reasons why farmers rarely get paid in full and on time. We believe that by first tackling the structured value chains - by improving working capital across them-you can learn key lessons around using technology to streamline their processes before moving on to the larger challengethe unstructured value chains.

\section{What has been one of your biggest "Aha!" moments while working with Umati Capital?}

Unfortunately, the life of an entrepreneur is filled with many unpredictable moments. There are countless "What just happened?" moments that leave you trying to make logical sense of events. I have concluded that luck and the right timing play a crucial part in my daily struggle.

My biggest "Aha!" moment came at the seed investment stage of Umati Capital. Like most startups at that stage, we barely had any cash and we rode purely on futuristic ideas about how Umati Capital would shape the lending sector in the years ahead. Thanks to the powers that be, we eventually closed an investment round with Accion Venture Labs worth USD400,000, at a valuation of USD1.4 million. What started off as a dream to change the way small and mediumsize enterprises in Africa access working capital had suddenly become a funded idea. I guess the scale and reality of what we were doing crystallized further in 2015, when we were recognized by Citigroup, Forbes magazine, MIT, and the MasterCard Foundation, among many global names. 
One of Kenya's own technology entrepreneurs who is also an investor in Umati Capital, Joseph Mucheru, has been appointed to the position of cabinet secretary in the Ministry of Information and Communications. What does this mean for the tech community?

First of all, Joe is an all-round good guy. He is unlike most who have achieved success at his level. His humility, coupled with his calm disposition, lets him work with people across different spectrums and backgrounds. I firmly believe he is the best person for the job. Joe is Google's former Sub-Saharan Africa lead, based in their Nairobi office. He was Google's first Sub-Saharan employee and was key in setting up Google's presence in Africa from 2007. Before joining Google, he worked in various roles, including chief technology officer and chief executive officer (CEO), at Wananchi Online (the leading provider of affordable entertainment and connectivity for East Africa's rapidly growing middle class), a company he co-founded in 1999.

What does Joe's appointment mean for the tech community? As much as the technology community is about creating scalable enterprises, we also want to see government changes aimed at the greater good of the nation. We believe Joe's vision and character can help create such an environment.

\section{What are some of the key areas that need to be digitized by the government?}

The overarching goal should be to achieve transparency through technology. The process of getting your ID card, passport, driver's license, National Hospital Insurance Fund card, or National Social Security Fund card needs to be digitized as soon as possible. By digitizing these processes, you will eradicate most of the daily corruption in the system. We also need to start digitizing basic government services in order to make those processes more transparent, less corrupt and, by that, more efficient. Another aspect is security. If you commit an offense in Nairobi, for example, two weeks later in Mombasa, the police will have no knowledge of your offense. Digitizing our security forces, beginning with the police, in a way that significantly minimizes corruption would be marvelous. 


\section{Why is the power of technology best deployed to combat corruption?}

At least once a week, there is a new corruption case that is opened up, and the annoying part of it all is that no one will be taken to jail. It is immensely frustrating! If we can put technology on the agenda that can actually minimize corruption by introducing new, transparent processes together with government leaders who own the process, then we are having a substantial impact on the lives of Kenyans. It is through technology and digitizing basic processes that we can transform Kenya in the shortest time possible.

\section{Thank you, Munyutu!} cation, adaptation, distribution and reproduction in any medium or format, as long as you give appropriate credit to the original author(s) and the source, provide a link to the Creative Commons license and indicate if changes were made.

The images or other third party material in this chapter are included in the work's Creative Commons license, unless indicated otherwise in the credit line; if such material is not included in the work's Creative Commons license and the respective action is not permitted by statutory regulation, users will need to obtain permission from the license holder to duplicate, adapt or reproduce the material. 